\title{
Does Recycling Contribute to Accounting Quality?
}

\author{
Melik Ertuğrul ${ }^{*}$ \\ Istinye University
}

\author{
Ali Coșkun ${ }^{* *}$ \\ Boğaziçi University
}

\begin{abstract}
As a result of amendments in existing financial reporting standards, certain items have been transferred (or recycled) from other comprehensive income to income statement since 2013. Based on a sample of Turkish listed firms over 2013-2018, we document the following outcomes for accounting quality, measured by value relevance and predictive power, of recycling. First, recycling is not value relevant, and net income with recycling and net income are equally value relevant. In other words, recycling does not provide useful information for valuation purposes. Second, net income with recycling and net income have statistically indifferent predictive powers.
\end{abstract}

Keywords: Value relevance, predictive power, recycling, reclassification, IAS 1, other comprehensive income JEL Classification: G14; M21; M41

\section{Yeniden Sinıflandırma Muhasebe Kalitesine Katkı Sunuyor mu?}

Öz

Mevcut finansal raporlama standartlarındaki değişimler neticesinde 2013 itibarıyla bazı muhasebe kalemlerinin diğer kapsamlı gelirden transfer edilerek gelir tablosunda yeniden sınıflandırıldığı görülmektedir. Bu çalışmada, 2013-2018 yılları arası borsada işlem gören Türk şirketlerine ilişkin bir örneklem ile yeniden sınıflandırmanın muhasebe kalitesi, değer ilişkisi ve gelecek nakit akışlarının tahmini penceresinden ele alınmaktadır. Birinci bulgumuz, yeniden sınıflandırmanın değer ilişkisi bulunmadığını ve net kar ile yeniden sınıflandırma ayarlaması yapılmış net karın değer ilişkilerinin birbirlerinden istatistiki olarak farksız olduğunu göstererek yeniden sınıflandırmanın değerleme için faydalı bilgi sunmadı̆̆ını ortaya koymaktadır. İkinci bulgumuz, bu iki kar kaleminin gelecek nakit akışlarının tahmininde birbirlerinden istatistiki olarak farksız olduğunu göstermektedir.

Anahtar Kelimeler: Değer ilişkisi, tahmin edicilik, aktarma, yeniden sınıflandırma, TMS 1, diğer kapsamlı gelir JEL Sinıflandırması: G14; M21; M41

\footnotetext{
*Melik ERTUGRUL, PhD Assistant Professor Chair, Department of Economics Manager, Technology Transfer Office Istinye University Topkapi Kampusu, Maltepe Mah. Edirne Cirpici Yolu, No.9 34010 Zeytinburnu/Istanbul/Turkey Phone: 00908502836000 E-mail: melik.ertugrul@istinye.edu.tr Web: https://iisbf.istinye.edu.tr/en/departments/economics/message-head-department

**Ali COSKUN, PhD Assistant Professor, Department of Management Bogazici University İ̈BF Fakultesi, Guney Kampus, Bogazici University Bebek/Istanbul/Turkey Phone: 00902123595400-6809 E-Mail: ali.coskun@boun.edu.tr Web: https://mgmt.boun.edu.tr/instructor/ali- coskun
} 


\section{Introduction}

Currently, the International Financial Reporting Standards (IFRS)-based financial reporting regime is in practice in most jurisdictions. ${ }^{1}$ The income reporting mechanism of IFRS is based on reporting only one aggregate income figure. As per International Accounting Standards (IAS) 1, that aggregate income figure, Comprehensive Income (CI), has two main subtotals: net income, which is the bottom line figure of the traditional profit and loss (P\&L) statement, and other comprehensive income (OCI). While these two subtotals refer to different transactions, they are indirectly connected to each other via recycling (or reclassification). As a relatively new component of OCI, recycling transfers an item from OCI to P\&L if the asset or liability behind that item is sold or derecognized (Hodgson \& Russell, 2014).

In our study, we analyse recycling by considering two major accounting quality dimensions: value relevance and predictive power. The value relevance research analyses the statistical association between accounting items and capital market figures (Francis \& Schipper, 1999) and the predictive power research investigates the statistical association between accounting items and future operating performance (Pronobis \& Zülch, 2011). Due to the complex structure of recycling, the literature (as in Arthur et al., 2017) majorly investigates recycling by considering the earnings management dimension of accounting quality. Although the concept of recycling has triggered very contentious arguments, academia has not examined recycling as a whole in detail by focusing on the value relevance and predictive power dimensions of accounting quality. In our study, by addressing this gap in the extant literature, we aim to provide beneficial insights for financial reporting regulation authorities and useful inputs for investors utilizing valuation models based on different performance measures.

There is very few research (e.g., Badertscher et al., 2014; Dong et al., 2014) providing findings for the value relevance of certain recycling items. Our study differs from them as we reveal evidence for the sum of all recycling items or recycling as a whole. In other words, we aim to show accounting quality of this sum instead of its components. The closest research to our study is Frendy and Semba (2017) analysing the usefulness of net income through OCI recycling. Our study complements Frendy and Semba (2017) in two distinct ways. First, Frendy and Semba (2017) document evidence by employing financial firms together with nonfinancial firms. This way of sampling is not a prevalent approach in capital markets-based accounting research since the financial reporting environment, income composition and capital structure of financial firms are distinctively different than the others. This sampling is not convenient for analysing recycling since financial firms frequently use recycling in line with their operating environments while this is not the case for the rest. To ensure our results are not driven by a particular industry's financial reporting regulations, we exclude financial firms, as well as utilities and holdings from our sample. Second, Frendy and Semba (2017) employ a sample of listed Japanese firms by covering the period 2012-2014. As shown by FSA (2015), the number of listed Japanese firms adopting IFRS is 10 (24) [52] as of the end of 2012 (2013) [2014]. ${ }^{2}$ Compared to Frendy and Semba's (2017) sample consisting of 1,902 firms, the number of IFRS adopters belonging to that period is so very small. In our study, we report outcomes for IFRS-based reported accounting items by maintaining accounting quality homogeneity in our sample. Furthermore, we draw a more comprehensive picture of the topic by covering the period over 2013-2018.

\footnotetext{
${ }^{1}$ As of the end of April 2018, more than $85 \%$ of jurisdictions, for which profiles were completed by the IFRS Foundation, mandate the IFRS-based financial reporting for all or most domestic publicly accountable entities.

${ }^{2}$ Note that IFRS-based financial reporting is not still mandatory even in 2018 although voluntary adoption was allowed in 2010 in Japan (Gray et al., 2019).
} 
By employing a sample of Turkish listed non-financial firms over 2013-2018, we document the following evidence for the value relevance and predictive power of recycling. First, consistent with Frendy and Semba (2017), the association between recycling and market value of equity is not significant at conventional levels. This outcome reveals that recycling is not value relevant alone and it does not convey useful information to stock market participants. Second, by adding recycling to net income, we compare the value relevance of this version of net income and traditional net income. We find that the impact of net income on market value of equity is not significantly different from the impact of net income with recycling on market value of equity. In other words, contrary to Frendy and Semba (2017), we conclude that both income measures are equally value relevant. Last, we report that net income and net income with recycling have statistically equal predictive powers. These outcomes remain insensitive to several robustness checks.

For our research, we focus on a sample of Turkish listed firms due to several important aspects. First, since international data vendors do not include either OCI or recycling data for most countries, documenting evidence for the topic may only be possible by collecting the data from annual reports which are overwhelmingly reported in the local language. For this reason, presenting outcomes based on a multinational sample is not possible for this (or a similar) topic. For instance, in his comprehensive literature review on the value relevance of CI, Ertuğrul (2019c) reveals that, with one exception, each study provides findings based on a single country sample. In our study, we manually collect necessary accounting information from financial statements, the great majority of which are reported in Turkish. The second aspect is the unique financial reporting environment of Turkey. As of 2013, Turkey has been implementing IFRS as published by the International Accounting Standards Board (IASB) (Cagle et al., 2015), which should be read as follows: there is no local regulatory intervention on existing standards which may eventually result in a hybrid version of IFRS (Nobes, 2011) and exert noise in accounting quality. Since Turkish accounting items do not contain noise induced by local authorities, Turkey provides a convenient setting for our research addressing accounting quality of recycling.

The rest of our study is structured as follows. Section 2 presents theoretical discussion including a literature review and hypotheses development. Section 3 describes the sample selection and methodology. Section 4 discusses results and Section 5 provides concluding remarks.

\section{Theoretical Discussion}

\section{Literature Review}

Research on the value relevance of OCI, which is a subset of CI, CI is considered close to our research because recycling is a subset of OCI. As OCI reporting is a relatively new concept, OCI and CI-based value relevance studies have come into the scene especially after 2015 (Ertuğrul, 2019c). Those studies do not provide a consensus on accounting quality of OCI. For instance, while Devalle and Magarini (2012), Veltri and Ferraro (2018) and Caliskan (2019) report no evidence for accounting quality of OCI, Mechelli and Cimini (2014), Yousefinejad et al. (2017) and Park (2018) conclude the opposite outcome. In a single study, Goncharov and Hodgson (2011) find evidence for accounting quality of OCI in 9 out of 16 analysed jurisdictions. Research on predictive power of CI is also considered similar to our research since recycling is a sub-component of CI. This research also does not provide consensus: while Dhaliwal et al. (1999) and Goncharov and Hodgson (2011) conclude that that net income 
predicts future operating performance better than CI, Kanagaretnam et al. (2009) and Pronobis and Zülch (2011) does not confirm this outcome. All in all, the extant literature on accounting quality of OCI provides mixed outcomes.

Although accounting quality literature contains several studies on OCI, it has very few research on accounting quality of recycling. Hence, in their comprehensive literature reviews, Barone and Gullkvist (2018), Black (2016) and Bradbury (2016) call for future research on recycling. In our literature review, we present the major outcomes of this limited literature. To our knowledge, only three studies are analysing the topic: Dong et al. (2014) and Badertscher et al. (2014) document outcomes based on samples including financial firms while Frendy and Semba (2017) report findings based on a sample including both financial and non-financial firms.

Dong et al. (2014) reveal that recycled accumulated gains and losses item has a significantly positive impact on both stock prices and returns by employing a dataset belonging to US commercial banks over 1998-2006. This outcome should be read as evidence for the value relevance of this recycling item. Dong et al. (2014) further show that this outcome is insensitive to the level of net interest income and the liquidity level of available-for-sale securities. Another evidence for financial firms is provided by Badertscher et al. (2014). Based on a sample of US bank holding companies over 2008-2011, Badertscher et al. (2014) find that investors have a differential pricing attitude towards recycled unrealized losses, and this attitude is more obvious for banks with low capital ratios. Outcomes of Badertscher et al. (2014) indicate that this recycling item is value relevant.

By employing a sample of Japanese firms over 2012-2014, Frendy and Semba (2017) report that the impact of recycling on stock prices is not significant at conventional levels, which refers that recycling is value irrelevant alone. However, Frendy and Semba (2017) find that net income with recycling is more value relevant than net income. Frendy and Semba (2017) reach this conclusion by comparing the explanatory values of separate regressions belonging to these two performance measures. Furthermore, they discuss that this significant value relevance difference disappears when they exclude financial firms from their sample. ${ }^{3}$ In other words, their outcomes for the whole sample are driven by financial firms. Lastly, Frendy and Semba (2017) report that recycling does not play a significant role in predicting future operating cash flows, which means that recycling has no predictive power.

All in all, the limited literature document evidence for the value relevance of recycling and certain recycling items of financial firms while there is only one study concluding value irrelevance and no predictive power of recycling for non-financial firms.

\section{Hypothesis Development}

The income concept has attracted the interest of both academia, standard setters, and practitioners. Beginning from the ground-breaking historical cost discussion of Paton and Littleton, the major focus of this interest has been on how to report income (Hodgson \& Russell, 2014; Rees \& Shane, 2012). Arguments on how to report income revolve around two main streams: Clean Surplus Approach and Dirty Surplus Approach. On the one hand, the Clean Surplus Approach supports that every transaction leading to a change in wealth as a result of non-owner transactions should flow through the income statement (Khan et al., 2018). On the

\footnotetext{
${ }^{3}$ Frendy and Semba (2017) do not provide regression tables belonging to these analyses.
} 
other hand, the Dirty Surplus Approach advocates the convenience of reporting income figures arising only from operating activities in the income statement (O'Hanlon \& Pope, 1999).

As the globally prevalent financial reporting regime, IFRS mandates the Clean Surplus Approach as the income reporting mechanism. Therefore, this approach shapes the current income reporting practice. As per this approach, by adding two subtotals (net income and OCI), a gross income measure, CI, is obtained. As a part of IFRS and in line with this approach, the Conceptual Framework considers the income statement the primary report illustrating an entity's financial performance; therefore, the main principle is presenting all revenues and expenses of the period in this statement (IASB, 2018, paragraph 7.17). Albeit being very particular to this principle, the IASB grants very few exemptions for certain circumstances. For instance, a change in the current value of an asset or liability is reported in OCI only if this exception provides more relevance and faithful representation in financial reporting. Furthermore, in order to achieve disclosure of more relevant financial information in a future period, revenues and expenses once reported in OCI are reclassified into P\&L in that future period (IASB, 2018, paragraph 7.19). As can be deducted from the IASB's mandate, the relevance of accounting information is the main concern in documenting financial performance through P\&L or OCI. Here, OCI provides additional and relevant information about items that do not directly show up in P\&L. Once reporting those items in P\&L, they are recycled and expected to become more relevant. Despite this emphasis on higher relevance, we underline that the concept of recycling was considered 'probably marginal' at very early stages (Detzen, 2016).

Recycling connects OCI and P\&L by transferring an item from a subtotal (OCI) to another subtotal (net income figure in P\&L) (Rees \& Shane, 2012). Recycling each item in OCI results in equal lifetime net income and lifetime comprehensive income figures. Currently, US Generally Accepted Accounting Standards require each OCI item to be recycled while IFRS does not allow for recycling certain OCI items (Hodgson \& Russell, 2014; Rees \& Shane, 2012). This attitude of IFRS may spring from the irony of 'probably marginal' stated by Detzen (2016). Indeed, the complexity of recycling is still discussed by standard setters and practitioners. For instance, double counting (Hodgson \& Russell, 2014; van Mourik \& Asami, 2018), reduced ability to extract and process information (Tarca et al., 2008) and evidence for earnings management (Arthur et al., 2017) have raised significant concerns for the complexity of recycling. Independent of such concerns, as underscored by Detzen (2016), the concept of income is very deficient without recycling which aims to maintain being the primary performance indicator role of income.

As highlighted in the IASB's mandate, relevance-related concerns point out the importance of recycling. Financial reporting information is only relevant if it influences the decisions of financial statement users. Since the general objective of financial reporting standard-setting is contributing to the decision-making of resource providers of the entity (IASB, 2010), IASB (2012) underlines that developments in IFRS aim to faithfully reflect not only the financial position but also the financial performance of a firm. In line with that vision, as a part of IFRS, IAS 1 requires CI reporting as a result of a revision which has become effective for annual reporting periods as of 2009. As a further revision, IAS 1 requires the practice of recycling which has become effective for annual reporting periods as of 2013 in most jurisdictions. ${ }^{4}$

\footnotetext{
${ }^{4}$ During the first four years of CI reporting, OCI included only one statement; afterwards, it includes two sub-statements: i) items reclassified to $\mathrm{P} \& \mathrm{~L}$ on derecognition, and ii) items that may not be reclassified to P\&L. For excellent overview of OCI, recycling, as well as recycling components, we refer the reader to Hodgson and Russell (2014).
} 
IFRS developers aim to create a single set of high-quality financial reporting standards (De George et al., 2016; Walker, 2010). In line with this high-quality emphasis, all revisions in IFRS should be considered evidence for efforts for improving IFRS as stated by NavarroGarcía and Madrid-Guijarro (2014, p. 156): "It is widely believed that IFRS have improved in quality during recent years due to the revision process and the issuing of new standards". In other words, developments in IFRS are performed in forms of either the issuing new standards or revising the existing ones. If revisions contribute to the ultimate merit of a single set of highquality financial reporting standards, the practice of recycling, which was introduced into IAS 1 as a revision, should result in better accounting quality from the perspective of IFRS developers. In line with this high-quality emphasis, we put forward the following three hypotheses:

H1: Net income with recycling is more value relevant than net income.

H2: Recycling is value relevant.

H3: Net income with recycling has more predictive power than net income.

\section{Sample Selection and Methodology}

\section{Sample Selection}

A sample of listed firms on Borsa Istanbul is employed to test our hypotheses. 2013 is the beginning year of our analyses since the practice of recycling was introduced as of 2013. Market value of equity figures, which are retrieved from the database of Borsa Istanbul, cover the latest possible data belonging to 2019 in order to reflect more recent outcomes. All financial reporting information over 2013-2018 is manually collected from annual financial statements available in the Public Disclosure Platform. After completing data collection, we shape the dataset by performing the following filters. First, financial institutions, holdings, and utilities are excluded since the financial reporting environment, income composition and capital structure of such firms are different than the others. Second, observations listed on the watchlist market are excluded as they have limited daily available trading time compared to the others. Third, if an observation has multiple listed shares, only the most liquid type is included. Fourth, observations without a fiscal year-end of December are excluded to keep reporting homogeneity of the sample. Fifth, observations with negative book value of equity figures are excluded because of going concern-related problems underscored by Gordon et al. (2010). Last, observations with any missing data required for analyses are excluded.

For value relevance analyses, we use a sample consisting of 1,419 firm-year observations and 273 firms. In predictive power analyses, there is a time lag between dependent and independent variables, which means losing several observations majorly belonging to 2013 . Therefore, for these analyses, we use a sample consisting of 1,187 firm-year observations and 269 firms.

\section{Methodology}

The value relevance research employs either the Price Model or the Return Model to perform analyses. Researchers may prefer one model to another depending on their research questions. Studies analysing the impact of an announcement on the market generally employ the Return Model (Hellström, 2006). However, our research question is to measure the valuation usefulness of a relatively new income concept, recycling. Hence, as illustrated by Hellström (2006) in detail, similar to most studies seeking the association between market data and accounting information, we utilize a modified linear Price Model very similar to Ohlson's (1995) valuation framework. 
To test our first hypothesis, we utilize Equations (1a) and (1b). If the regression coefficient of net income with recycling in Equation (1b) is significantly greater than the regression coefficient of net income in Equation (1a), our first hypothesis is confirmed. To test our second hypothesis, we utilize Equation (2). A statistically significant (and preferably positive) regression coefficient $\left(\beta_{3}\right)$ of recycling provides evidence for our second hypothesis.

$$
\begin{aligned}
& \text { Equation (1a): } \mathrm{MV}_{\mathrm{i}, \mathrm{t}+1}=\beta_{0}+\beta_{1} \times \mathrm{BV}_{\mathrm{i}, \mathrm{t}}+\beta_{2} \times \mathrm{NI}_{\mathrm{i}, \mathrm{t}}+\varepsilon_{\mathrm{i}, \mathrm{t}} \\
& \text { Equation (1b) : } \mathrm{MV}_{\mathrm{i}, \mathrm{t}+1}=\beta_{0}+\beta_{1} \times \mathrm{BV}_{\mathrm{i}, \mathrm{t}}+\beta_{2} \times \mathrm{NI}_{\mathrm{REC}} \mathrm{REC}_{\mathrm{i}, \mathrm{t}}+\varepsilon_{\mathrm{i}, \mathrm{t}} \\
& \text { Equation (2) : } \mathrm{MV}_{\mathrm{i}, \mathrm{t}+1}=\beta_{0}+\beta_{1} \times \mathrm{BV}_{\mathrm{i}, \mathrm{t}}+\beta_{2} \times \mathrm{NI}_{\mathrm{i}, \mathrm{t}}+\beta_{3} \times \mathrm{REC}_{\mathrm{i}, \mathrm{t}}+\varepsilon_{\mathrm{i}, \mathrm{t}}
\end{aligned}
$$

where i, t, MV, BV, NI, NI_REC, and REC respectively represent firm, year, market value of equity, book value of equity, net income, net income with recycling, and recycling. Market value of equity is measured after three months from the fiscal year-end. We obtain book value of equity by subtracting liabilities and net income from total assets. Net income is the bottomline traditional net income. Recycling is the sum figure reported in the OCI statement. NI_REC is obtained by adding recycling to the bottom-line net income. The Price Model is criticized due to the scale effect problem, as well as the stale information effect problem (see, among others, Brown et al., 1999; Easton \& Sommers, 2003; Kothari \& Zimmerman, 1995). By following concrete and convincing outcomes of Goncharov and Veenman (2014), we deflate each variable in the above Equations by lagged market value of equity to mitigate the impact of these problems on our regression outcomes.

To test our third hypothesis, by following Lee and Kim (2019), we utilize Equations (3a) and (3b). If the regression coefficient of net income with recycling in Equation (3b) is reported as significantly greater than the regression coefficient of net income in Equation (3a), our third hypothesis is confirmed.

$$
\begin{aligned}
& \text { Equation (3a) : } \mathrm{OCF}_{\mathrm{i}, \mathrm{t}+1}=\beta_{0}+\beta_{1} \times \mathrm{OCF}_{\mathrm{i}, \mathrm{t}}+\beta_{2} \times \mathrm{NI}_{\mathrm{i}, \mathrm{t}}+\varepsilon_{\mathrm{i}, \mathrm{t}} \\
& \text { Equation (3b) : } \mathrm{OCF}_{\mathrm{i}, \mathrm{t}+1}=\beta_{0}+\beta_{1} \times \mathrm{OCF}_{\mathrm{i}, \mathrm{t}}+\beta_{2} \times \mathrm{NI}_{-} \mathrm{REC}_{\mathrm{i}, \mathrm{t}}+\varepsilon_{\mathrm{i}, \mathrm{t}}
\end{aligned}
$$

where OCF is net cash flow from operating activities and other variables are defined above in detail. Due to scale effect-related problems, each variable in Equations (3a) and (3b) is deflated by total assets consistent with the literature.

Correlations between standard errors should be investigated to obtain unbiased standard errors. Gow et al. (2010) clearly illustrate that accounting items have greater cross-sectional dependence and serial dependence than finance variables such as returns. Hence, their groundbreaking research reveals that correcting standard errors for both types of dependence significantly changes regression outcomes. Petersen (2009) and Gow et al. (2010) underscore that research generally considers cross-sectional dependence while it does not take serial dependence into account. As per concerns of Petersen (2009) and Gow et al. (2010), we check whether serial dependence biases our standard errors: the Woolridge Test, which is more flexible and requires fewer assumptions compared to other tests (Drukker, 2003), shows evidence for serial dependence which may make our standard errors less efficient. Therefore, we control for serial dependence, in addition to cross-sectional dependence, in our standard errors by clustering them at both the firm level and the year level.

In order to statistically compare variables of interest in Equations (1a) and (1b), as well as Equations (3a) and (3b), we follow Paternoster et al's (1998) approach to obtain the unbiased 
estimate of the standard deviation of the sampling distribution. Hence, we employ Formula (1) where $\beta_{a}$ and $\beta_{b}$ are regression coefficients, and $\operatorname{SE}\left(\beta_{a}\right)$ and $\operatorname{SE}\left(\beta_{b}\right)$ represent standard errors of $\beta_{a}$ and $\beta_{b}$, respectively. Sub-letters a and $\mathrm{b}$ refer to the variable of interest in Equations (1a) \& (3a) and (1b) \& (3b).

$$
\text { Formula (1) }: \mathrm{Z}=\left(\beta_{a}-\beta_{b}\right) /\left[\mathrm{SE}\left(\beta_{a}\right)^{2}+\mathrm{SE}\left(\beta_{b}\right)^{2}\right]^{1 / 2}
$$

Since we do not want our regression outcomes to be significantly driven by extreme values and possible data errors, all variables are winsorized at the top and bottom $1 \%$. Before developing our analyses, we perform pooled OLS for each equation, followed by the Variance Inflation Factor (VIF) analysis. For each Equation, all individual VIF values and the mean VIF value are reported as considerably smaller than the critical VIF value of 10 . These outcomes should be read as evidence for the non-presence of the multicollinearity problem at conventional statistical significance levels.

After these multicollinearity checks, the correct regression method should be determined to obtain correct value relevance inferences, as highlighted by Ertuğrul and Demir (2018) and Onali et al. (2017). Therefore, the Hausman Test is performed for each value relevance Equation. All outcomes provided by the Hausman Test suggest that the fixed effects methodology, which controls for the firm-level unobserved heterogeneity, should be employed. Therefore, all value relevance outcomes are obtained by performing the fixed effects methodology. For predictive power analyses, even though the outcome of the Hausman Test provides concrete evidence for employing the fixed effects methodology, using this methodology may not be convenient because Equations (3a) and (3b) include the lagged dependent variable as one of the independent variables. Note that, as illustrated by Ertuğrul and Demir (2018) in detail, the fixed effects methodology performs a demeaning process indeed. Since one of the independent variables is the lagged dependent variable, demeaning almost the same thing twice at different sides of an equation may not be a convenient approach. Hence, we prefer performing pooled OLS regressions for predictive power analyses. Another source of unobserved heterogeneity is at the time level (Ertuğrul \& Demir, 2018) which may significantly affect regression outcomes. For instance, Alali and Foote (2012) underscore that bearish/bullish market trends may affect value relevance inferences. Therefore, we employ year dummies in all research settings to mitigate the impact of time fixed effects on our regression outcomes. All in all, we reduce the potential bias by controlling for these two unobserved heterogeneity types.

\section{Results}

\section{Descriptive Statistics and Correlation Matrix}

Certain descriptive characteristics of our sample are presented in Panel A of Table 1. Note that i) except for OCF, all variables are deflated by lagged market value of equity, and ii) OCF is deflated by total assets. Above 1 mean market value of equity figure indicates that firms in our sample grow annually. Furthermore, below 1 mean book value of equity figure should be read as follows: firms are traded at a premium to book value of equity. Additionally, the mean income figure points out that firms in our sample do not suffer from profitability-related problems. Moreover, the mean (and also median) figures belonging to net income and net income with recycling are obviously different. It may be an indication of the materiality of recycling. Last, the operating cash flow generation power of an average firm in our sample is around $5 \%$ of total assets. 


\section{[INSERT TABLE 1 HERE]}

Panel B (C) reveals the correlation matrix belonging to value relevance (predictive power) analyses. In Panel B, except for recycling, all variables are significantly and positively correlated with market value of equity. Furthermore, book value of equity is negatively correlated with both types of income while it is significantly and positively correlated with recycling. There is also no significant correlation between net income and recycling. In Panel $\mathrm{C}$, all correlation coefficients are reported as significantly positive. More importantly, the correlation coefficient between OCF and lagged OCF is the smallest figure which may indicate the weak persistence of OCF. Since a correlation matrix provides a sole association between two variables, VIF analyses should be performed to check the statistical presence of multicollinearity if any. As discussed in the previous section, for each setting, all individual VIF figures, as well as the mean VIF figure, are very close to one which should be read as no statistical evidence for the multicollinearity problem.

\section{Multivariate Analyses}

Regression outcomes belonging to our value relevance analyses are presented in Panel A of Table 2. All regression coefficients of book value of equity and net income are reported as significantly positive which should be read as evidence for the value relevance of these accounting items. These outcomes are consistent with the research documenting outcomes for the value relevance of accounting information by employing samples of Turkish listed firms after the recent global financial crisis. ${ }^{5}$ Furthermore, the regression coefficient of net income with recycling is reported as positive at $1 \%$ significance level which means that this item is value relevant. All these significantly positive regression coefficients indicate that each of these accounting items positively affects market value of equity.

Panel A of Table 2 sheds light on our first two hypotheses. First, the regression coefficient of net income is greater than that of net income with recycling. However, the difference between these two regression coefficients is not reported as significant at conventional levels, which should be read as follows: the market does not significantly distinguish these two income measures. Therefore, this insignificant difference indicates that these two income measures are equally value relevant and it does not confirm our first hypothesis which argues that net income with recycling is more value relevant than net income. This outcome is not in line with Frendy and Semba (2017). By comparing $\mathrm{R}^{2}$ figures separately obtained for these two income measures, Frendy and Semba (2017) conclude that net income with recycling is more value relevant than net income. ${ }^{6}$ However, Frendy and Semba (2017) report this outcome for a sample consisting of both financial and non-financial firms. When their analyses are reperformed for a sample consisting of only non-financial firms, Frendy and Semba (2017) find that both performance measures are equally value relevant. Second, the association between recycling and market value of equity is not reported as statistically significant which means that this item does not convey additional useful information to the market. Hence, in line with Frendy and Semba (2017), we conclude that recycling is value irrelevant. This outcome does not support our second hypothesis which discusses that recycling is value relevant. Note that our outcomes are not comparable to Dong et al. (2014) and Badertscher et al. (2014) because i) our recycling measure is a sum figure while they report outcomes for certain recycling items, and ii) they document outcomes based on samples consisting of only financial firms.

\footnotetext{
${ }^{5}$ Among others, see Ates (2020), Ertuğrul (2019b, 2020), Ertuğrul and Demir (2018) and Gökten and Atalay (2019).

${ }^{6}$ Since $\mathrm{R}^{2}$ measures may be seriously affected and inflated by the presence of other variables including especially dummies (Ertuğrul, 2019b), it may indicate incorrect inferences. We perform our Formula (1) to outcomes reported in Table 5 of Frendy and Semba (2017) and we realize that these two income measures are equally value relevant indeed.
} 


\section{[INSERT TABLE 2 HERE]}

Panel B of Table 2 answers our third hypothesis. All regression coefficients of lagged OCF are reported as significantly positive which means that lagged OCF figures have statistically significant predictive power on current OCF figures. This outcome is in line with most literature. ${ }^{7}$ Furthermore, associations between $\mathrm{OCF}$ and both income measures are significantly positive. Regression coefficients of lagged OCF are considerably less than regression coefficients of both income measures, which indicate that both income measures are superior to lagged OCF in predicting future OCF. Moreover, although the regression coefficient of net income is slightly greater than the regression coefficient of net income with recycling, the difference between these regression coefficients is not reported as significant at conventional levels. To illustrate, the predictive powers of both income measures are not superior to each other. This outcome does not confirm our last hypothesis which claims that net income with recycling has more predictive power than net income.

All in all, our findings reveal that the recycling amendment introduced into IAS 1 does not improve accounting quality measured by the value relevance and predictive power. Our outcomes do not give a concrete ground for the vision of IFRS developers who are believed to improve the quality of IFRS by revisions, as well as the issuing of new standards (NavarroGarcía \& Madrid-Guijarro, 2014). In other words, our outcomes indicate that recycling does not contribute to the single set of high-quality financial reporting standards target of IFRS developers.

\section{Robustness Analyses}

In this section, additional analyses are presented to increase the robustness of our findings. First, in his extensive literature review, Ertuğrul (2019a) reveals that the value relevance literature employs different market value of equity figures measured for different month-ends as a robustness check. Hence, we re-perform our analyses with the dependent variable of market value of equity measured after 4 months from the fiscal year-end and present outcomes of these analyses in Panel A of Table 3. Second, to mitigate potential econometric problems spring from using the lagged dependent variable as one of the independent variables in our predictive power analyses, we re-perform Equations ( $3 a$ ) and ( $3 b$ ) by excluding lagged OCF as performed by Demir et al. (2013) and present outcomes of these analyses in Panel B of Table 3. Third, as there are too many (almost $40 \%$ of the whole sample) observations with zero recycling figures, we exclude such observations and re-perform all analyses for the rest. Table 4 reveals outcomes of these analyses. Last, since the impact of singleton observations may significantly change significance levels (Correia, 2015) which may lead to incorrect inferences, we re-perform all regressions by excluding singleton observations. We do not present those outcomes for the sake of brevity. ${ }^{8}$

\section{[INSERT TABLE 3 HERE]}

[INSERT TABLE 4 HERE]

All outcomes reported in Tables 3 and 4, as well as our untabulated last robustness check, reveal that outcomes presented in Table 2 are not sensitive to different dependent variable measurements, using the lagged dependent variable, zero recycling figures, as well as singleton

\footnotetext{
${ }^{7}$ Among others, see Ertugay (2013) and Lee and Kim (2019).

${ }^{8}$ Those outcomes are available from the authors.
} 
observations. In other words, all these robustness checks confirm outcomes presented in Table 2: i) net income with recycling is as value relevant as net income, ii) recycling is not value relevant, and iii) net income with recycling and net income have statistically equal predictive powers.

\section{Conclusion}

In our study, we investigate whether the practice of recycling introduced into IAS 1 improves accounting quality by considering the value relevance and predictive power analyses. Based on a sample of listed firms on Borsa Istanbul from 2013 to 2018, we perform regressions by employing a modified linear Price Model very similar to Ohlson's (1995) valuation framework and document the following outcomes. First, both net income and net income with recycling affect market value of equity in a statistically indifferent manner. In other words, these income measures are equally value relevant. Second, the impact of recycling on market value of equity is not statistically significant which should be read as evidence for the value irrelevance of recycling. Last, the predictive power of net income is not statistically different from the predictive power of net income with recycling. Overall, our outcomes reveal that recycling does not i) carry information for market participants alone, and ii) improve accounting quality of net income.

Our study points out several insights for regulatory authorities and equity investors. The limited literature (e.g., Badertscher et al., 2014; Dong et al., 2014; Frendy \& Semba, 2017)) concludes that recycling or some of its components yield useful information for financial firms. We contribute to this scarce literature by providing that recycling does not improve accounting quality, analysed by the value relevance and predictive power, of non-financial firms. Note that IFRS is the prevalently implemented financial reporting regime in most jurisdictions and we reveal our outcomes belonging to IFRS-based accounting figures. Hence, our outcomes may be of interest to IFRS developers who may take future actions including the issuing of new standards and/or revisions in existing ones by considering our outcomes to make recycling, as well as net income with recycling, provide higher accounting quality. Moreover, the existing version of recycling is criticized for certain aspects that spring mainly from its complexity as discussed by Tarca et al. (2008), Hodgson and Russell (2014) and van Mourik and Asami (2018). Our outcomes may lead to designing future regulations to reduce the complexity of recycling and alleviate other criticisms against recycling. Furthermore, by concluding accounting quality irrelevance of recycling, our study provides useful inputs for global equity investors who utilize accounting-based valuation models. Hence, our outcomes should also be the interest of global equity investors.

Our study provides directions for future research. The generalizability of our outcomes is limited because we document our outcomes based on a sample of a single jurisdiction. Future research may depict a comprehensive picture of the topic by analysing a sample including several jurisdictions. We underline that global databases provide very incomplete and mostly missing recycling figures, especially for emerging economies, and future research should be aware of this incomplete data problem. For that reason, we (as in almost all studies in the literature review of Ertuğrul (2019c)) manually collect financial statement items including recycling to have a complete dataset and mitigate the impact of missing data on our regression analyses. Second, future research may extend our study by considering components of recycling. A very extensive manual data collection is also required for such analyses due to the aforementioned incomplete data problem. Despite these limitations, we wishfully believe that our study provides beneficial outcomes to academia, regulators, and investors. 


\section{References}

Alali, F. A., \& Foote, P. S. (2012). The Value Relevance of International Financial Reporting Standards: Empirical Evidence in an Emerging Market. International Journal of Accounting, 47(1), 85-108.

Arthur, N., Clout, V., Wu, A., \& Zhou, X. (2017). Earnings Management Using OCI Recycling: Australian Evidence. European Accounting Association $40^{\text {th }}$ Annual Congress. Valencia, Spain, 10-14 May 2017.

Ates, S. (2020). Membership of sustainability index in an emerging market: Implications for sustainability. Journal of Cleaner Production, 250, 119465.

Badertscher, B. A., Burks, J. J., \& Easton, P. D. (2014). The market pricing of other-thantemporary impairments. Accounting Review, 89(3), 811-838.

Barone, E., \& Gullkvist, B. (2018). Academic Literature Review Interaction of IFRS 9 and long-term investment decisions. EFRAG Brussels, Belgium.

Black, D. E. (2016). Other Comprehensive Income: A Review and Directions for Future Research. Accounting and Finance, 56, 9-45.

Bradbury, M. E. (2016). Discussion of 'other comprehensive income: a review and directions for future research. Accounting and Finance, 56(1), 47-58.

Brown, S., Lo, K., \& Lys, T. (1999). Use of $\mathrm{R}^{2}$ in accounting research: measuring changes in value relevance over the last four decades. Journal of Accounting and Economics, 28(2), $83-115$.

Cagle, M. N., Kaytmaz Balsarı, Ç., \& Dalkılıç, A. F. (2015). Have We Really Been Using the International Financial Reporting Standards (IFRS) since 2005? Case of Turkey. International Journal of Social Sciences and Humanity Studies, 7(1), 36-46.

Caliskan, A. (2019). Kapsamlı Gelir Raporlamasının Değer ilişkisi [Unpublished master's thesis]. Istinye University.

Correia, S. (2015). Singletons, cluster-robust standard errors and fixed effects: A bad mix. Technical Note, Duke University.

De George, E. T., Li, X., \& Shivakumar, L. (2016). A review of the IFRS adoption literature. Review of Accounting Studies, 21(3), 898-1004.

Demir, V., Bahadir, O., \& Oncel, A. G. (2013). What is the Best Measure of Financial Performance? Comprehensive Income versus Net Income: Evidence from Turkey. Iktisat, İsletme ve Finans, 28, 73-96.

Detzen, D. (2016). From compromise to concept? - a review of "other comprehensive income." Accounting and Business Research, 46(7), 760-783.

Devalle, A., \& Magarini, R. (2012). Assessing the value relevance of total comprehensive income under IFRS: an empirical evidence from European stock exchanges. International Journal of Accounting, Auditing and Performance Evaluation, 8(1), 4368.

Dhaliwal, D., Subramanyam, K. R., \& Trezevant, R. (1999). Is comprehensive income superior to net income as a measure of firm performance? Journal of Accounting and Economics, 26(1), 43-67. 
Dong, M., Ryan, S., \& Zhang, X.-J. (2014). Preserving amortized costs within a fair-valueaccounting framework: reclassification of gains and losses on available-for-sale securities upon realization. Review of Accounting Studies, 19(1), 242-280.

Drukker, D. M. (2003). Testing for serial correlation in hierarchical linear models. The State Journal, 3(2), 168-177.

Easton, P. D., \& Sommers, G. A. (2003). Scale and the Scale Effect in Market-based Accounting Research. Journal of Business Finance and Accounting, 30(1-2), 25-55.

Ertugay, E. (2013). Gelecekteki nakit akışlarının tahmininde nakit akışlarının ve tahakkukların rolü [Unpublished doctoral dissertation]. Ankara University.

Ertuğrul, M. (2019a). A Review of the Literature on IFRS Adoption From the Perspective of the Value Relevance. In H. Dincer \& S. Yüksel (Eds.), Handbook of Research on Global Issues in Financial Communication and Investment Decision Making (pp. 367-394). IGI Global.

Ertuğrul, M. (2019b). Interpretation of the Value Relevance Indicator With(out) Dummies: Demeaning. In H. Dincer \& S. Yüksel (Eds.), Handbook of Research on Global Issues in Financial Communication and Investment Decision Making (pp. 192-213). IGI Global.

Ertuğrul, M. (2019c). Kapsamlı Gelirin Değer İlişkisine Yönelik Uluslararası Literatür Taramas1. Mali Çözüm, 155, 55-80.

Ertuğrul, M. (2020). Maddi Olmayan Duran Varlıkların Değer İlişkisi. Muhasebe ve Denetime Bakış, 59, 213-233.

Ertuğrul, M., \& Demir, V. (2018). How Does Unobserved Heterogeneity Affect Value Relevance? Australian Accounting Review, 28(2), 288-301.

Francis, J., \& Schipper, K. (1999). Have Financial Statements Lost Their Relevance? Journal of Accounting Research, 37(2), 319-352.

Frendy, H., \& Semba, D. (2017). Does recycling improve information usefulness of income? The case of Japan. Asian Review of Accounting, 25(3), 376-403.

FSA (2015). IFRS Adoption Report, Financial Services Agency, Tokyo.

Gökten, S., \& Atalay, B. (2019). Bilanço Dışı Varlıkların Muhasebe Bilgisinin Değer İlgililiği Üzerindeki Etkisi: Türkiye'ye Özgü Bulgular. Muhasebe ve Vergi Uygulamaları Dergisi, 12(2), 271-288.

Goncharov, I., \& Hodgson, A. (2011). Measuring and Reporting Income in Europe. Journal of International Accounting Research, 10(1), 27-59.

Goncharov, I., \& Veenman, D. (2014). Stale and Scale Effects in Markets-Based Accounting Research: Evidence from the Valuation of Dividends. European Accounting Review, 23(1), 25-55.

Gordon, L. A., Loeb, M. P., \& Sohail, T. (2010). Market Value of Voluntary Disclosure Concerning Information Security. MIS Quarterly, 34(3), 567-594.

Gow, I. D., Ormazabal, G., \& Taylor, D. J. (2010). Correcting for Cross-Sectional and TimeSeries Dependence in Accounting Research. Accounting Review, 85(2), 483-512. 
Gray, S. J., Nagata, K., Nakamura, M., \& Ozu, C. (2019). Voluntary Adoption of IFRS: What Motivates Japanese Firms to Voluntarily Adopt IFRS? SSRN Electronic Journal. Available at SSRN: https://ssrn.com/abstract=3364253 or http://dx.doi.org/10.2139/ssrn.3364253

Hellström, K. (2006). The Value Relevance of Financial Accounting Information in a Transition Economy: The Case of the Czech Republic. European Accounting Review, 15(3), 325-349.

Hodgson, A., \& Russell, M. (2014). Comprehending Comprehensive Income. Australian Accounting Review, 24(2), 100-110.

IASB. (2010). The Conceptual Framework for Financial Reporting. International Accounting Standards Board, London

IASB. (2012). Report of the Trustees' Strategy Review 2011. International Accounting Standards Board, London

IASB. (2018). The Conceptual Framework. International Accounting Standards Board, London

Kanagaretnam, K., Krishnan, G. V., \& Lobo, G. J. (2009). Is the market valuation of banks' loan loss provision conditional on auditor reputation? Journal of Banking and Finance, 33(6), 1039-1047.

Khan, S., Bradbury, M. E., \& Courtenay, S. (2018). Value Relevance of Comprehensive Income. Australian Accounting Review, 28(2), 279-287.

Kothari, S. P., \& Zimmerman, J. L. (1995). Price and return models. Journal of Accounting and Economics, 20(2), 155-192.

Lee, J., \& Kim, E. (2019). Foreign monitoring and predictability of future cash flow. Sustainability, 11(18), 1-22.

Mechelli, A., \& Cimini, R. (2014). Is Comprehensive Income Value Relevant and Does Location Matter? A European Study. Accounting in Europe, 11(1), 59-87.

Navarro-García, J. C., \& Madrid-Guijarro, A. (2014). The Influence of Improvements in Accounting Standards on Earnings Management: The Case of IFRS. Australian Accounting Review, 24(2), 154-170.

Nobes, C. (2011). IFRS Practices and the Persistence of Accounting System Classification. Abacus, 47(3), 267-283.

O'Hanlon, J. F., \& Pope, P. F. (1999). The Value-Relevance of UK Dirty Surplus Accounting Flows. British Accounting Review, 31, 459-482.

Ohlson, J. A. (1995). Earnings, Book Values, and Dividends in Equity Valuation. Contemporary Accounting Research, 11(2), 661-687.

Onali, E., Ginesti, G., \& Vasilakis, C. (2017). How should we estimate value-relevance models? Insights from European data. British Accounting Review, 49(5), 460-473.

Park, H. (2018). Market Reaction to Other Comprehensive Income. Sustainability, 10(6), 113.

Paternoster, R., Brame, R., Mazerolle, P., \& Piquiero, A. (1998). Using the Correct Statistical 
Test for the Equality of Regression Coefficients. Criminology, 36(4), 859-866.

Petersen, M. A. (2009). Estimating standard errors in finance panel data sets: Comparing approaches. Review of Financial Studies, 22(1), 435-480.

Pronobis, P., \& Zülch, H. (2011). The predictive power of comprehensive income and its individual components under IFRS. Problems and Perspectives in Management, 9(4), 72-88.

Rees, L. L., \& Shane, P. B. (2012). Academic Research and Standard-Setting: The Case of Other Comprehensive Income. Accounting Horizons, 26(4), 789-815

Tarca, A., Hancock, P., Woodliff, D., Brown, P., Bradbury, M., \& van Zijl, T. (2008). Identifying decision useful information with the matrix format income statement. Journal of International Financial Management and Accounting, 19(2), 184-217.

van Mourik, C., \& Asami, Y. K. (2018). Articulation, Profit or Loss and OCI in the IASB Conceptual Framework: Different Shades of Clean (or Dirty) Surplus. Accounting in Europe, 15(2), 167-192.

Veltri, S., \& Ferraro, O. (2018). Does other comprehensive income matter in credit-oriented systems? Analyzing the Italian context. Journal of International Accounting, Auditing and Taxation, 30, 18-31.

Walker, M. (2010). Accounting for varieties of capitalism: The case against a single set of global accounting standards. British Accounting Review, 42(3), 137-152.

Yousefinejad, M., Ahmad, A., \& Embong, Z. (2017). Value relevance of other comprehensive income and its Available-For-Sale Financial Instruments (AFS) and Revaluation Surplus of Property, Plant and Equipment (REV) components. Asian Journal of Accounting and Governance, 8, 133-143. 


\section{Appendix}

\section{Table 1}

Descriptive Statistics and Correlation Matrices.

Panel A shows descriptive statistics. Panels B and C present correlation matrices. MV, BV, NI, NI_REC, REC and OCF respectively refer to market value of equity measured after 3 months from the fiscal year-end, book value of equity, net income, net income with recycling, recycling, and operating cash flows. All variables in Panels A and B are deflated by lagged MV while all variables in Panel $\mathrm{C}$ are deflated by total assets. L. stands for lagged version of the following item: i.e., L.CFO means lagged operating cash flows. N, MEAN, P50, SD, MIN, and MAX refer to the total number of observations, mean, median, standard deviation, minimum, and maximum. $* * * \mathrm{p}<0.01, * * \mathrm{p}<0.05, * \mathrm{p}<0.1$.

\begin{tabular}{|c|c|c|c|c|c|c|}
\hline PANEL A & & & & & & \\
\hline & $\mathbf{N}$ & MEAN & P50 & SD & MIN & MAX \\
\hline MV & 1419 & 1.1600 & 1 & 0.6310 & 0.3140 & 4.2770 \\
\hline BV & 1419 & 0.9490 & 0.7200 & 0.8160 & 0.0719 & 4.6420 \\
\hline NI & 1419 & 0.0234 & 0.0483 & 0.2280 & -0.9200 & 0.7470 \\
\hline NI_REC & 1419 & 0.0340 & 0.0521 & 0.2360 & -0.9220 & 0.8100 \\
\hline REC & 1419 & 0.0100 & 0 & 0.0432 & -0.0692 & 0.2710 \\
\hline OCF & 1187 & 0.0536 & 0.0479 & 0.1110 & -0.2700 & 0.4690 \\
\hline \multicolumn{7}{|l|}{ PANEL B } \\
\hline & MV & BV & NI & NI_REC & REC & \\
\hline MV & 1 & & & & & \\
\hline BV & $0.1681^{* * *}$ & 1 & & & & \\
\hline NI & $0.1566^{* * *}$ & $-0.0998 * * *$ & 1 & & & \\
\hline NI_REC & $0.1698 * * *$ & $-0.0640 * * *$ & $0.9716 * * *$ & 1 & & \\
\hline REC & 0.0396 & $0.1194 * * *$ & -0.0101 & $0.2043^{* * *}$ & 1 & \\
\hline \multicolumn{7}{|l|}{ PANEL C } \\
\hline & OCF & L.OCF & L.NI & L.NI_REC & & \\
\hline OCF & 1 & & & & & \\
\hline L.OCF & $0.2791 * * *$ & 1 & & & & \\
\hline L.NI & $0.3598 * * *$ & $0.3406^{* * *}$ & 1 & & & \\
\hline L.NI_REC & $0.3529 * * *$ & $0.3408 * * *$ & $0.9716 * * *$ & 1 & & \\
\hline
\end{tabular}




\section{Table 2}

Regression Outcomes

Panel A (B) presents outcomes of value relevance (predictive power) analyses. BV, NI, NI_REC, REC and OCF respectively refer to book value of equity, net income, net income with recycling, recycling, and operating cash flows. In Panel B (A), the dependent variable is OCF (market value of equity measured after 3 months from the fiscal year-end) and all variables are deflated by total assets (lagged market value of equity). L. stands for lagged version of the following item: i.e., L.NI means lagged net income. In each Panel, the difference row shows the regression coefficient difference between NI and NI_REC. In Panel A, regression outcomes are obtained by the fixed effects methodology. In all Panels, year fixed effects are controlled. Standard errors in parentheses are clustered at both the firm level and the year level. $* * * p<0.01$, $* * \mathrm{p}<0.05, * \mathrm{p}<0.1$.

\begin{tabular}{|c|c|c|c|}
\hline \multicolumn{4}{|l|}{ PANEL A } \\
\hline & Equation (1a) & Equation (1b) & Equation (2) \\
\hline BV & $\begin{array}{c}0.5517 * * * \\
(0.0908)\end{array}$ & $\begin{array}{c}0.5389 * * * \\
(0.0870)\end{array}$ & $\begin{array}{c}0.5507 * * * \\
(0.0891)\end{array}$ \\
\hline NI & $\begin{array}{c}0.7557 * * \\
(0.2056)\end{array}$ & & $\begin{array}{l}0.7567 * * \\
(0.2088)\end{array}$ \\
\hline NI_REC & & $\begin{array}{l}0.7330 * * \\
(0.2017)\end{array}$ & \\
\hline REC & & & $\begin{array}{c}0.1060 \\
(0.6711)\end{array}$ \\
\hline Constant & $\begin{array}{c}0.6187 * * * \\
(0.0896)\end{array}$ & $\begin{array}{c}0.6236 * * * \\
(0.0871)\end{array}$ & $\begin{array}{c}0.6185^{* * * *} \\
(0.0899)\end{array}$ \\
\hline $\begin{array}{l}\text { Number of Obs. } \\
\mathbf{R}^{2}\end{array}$ & $\begin{array}{l}1,419 \\
0.412\end{array}$ & $\begin{array}{l}1,419 \\
0.412\end{array}$ & $\begin{array}{l}1,419 \\
0.412\end{array}$ \\
\hline Difference & \multicolumn{2}{|c|}{-0.0227} & \\
\hline \multicolumn{4}{|l|}{ PANEL B } \\
\hline & Equation (3a) & Equation (3b) & \\
\hline L.OCF & $\begin{array}{c}0.1847 * * * \\
(0.0263)\end{array}$ & $\begin{array}{c}0.1873 * * * \\
(0.0267)\end{array}$ & \\
\hline L.NI & $\begin{array}{c}0.3661 * * * \\
(0.0457)\end{array}$ & & \\
\hline L.NI_REC & & $\begin{array}{c}0.3459 * * * \\
(0.0441)\end{array}$ & \\
\hline Constant & $\begin{array}{c}0.0310 * * * \\
(0.0011)\end{array}$ & $\begin{array}{c}0.0304 * * * \\
(0.0014)\end{array}$ & \\
\hline Number of Obs. & 1,187 & 1,187 & \\
\hline $\mathbf{R}^{2}$ & 0.160 & 0.156 & \\
\hline Difference & \multicolumn{2}{|c|}{-0.0202} & \\
\hline
\end{tabular}




\section{Table 3}

Robustness Analyses I

Panel A (B) presents outcomes of value relevance (predictive power) analyses. BV, NI, NI_REC, REC and OCF respectively refer to book value of equity, net income, net income with recycling, recycling, and operating cash flows. In Panel B (A), the dependent variable is OCF (market value of equity measured after 4 months from the fiscal year-end) and all variables are deflated by total assets (lagged market value of equity). L. stands for lagged version of the following item: i.e., L.NI means lagged net income. In each Panel, the difference row shows the regression coefficient difference between NI and NI_REC. In Panel A, regression outcomes are obtained by the fixed effects methodology. In all Panels, year fixed effects are controlled. Standard errors in parentheses are clustered at both the firm level and the year level. *** $\mathrm{p}<0.01$, $* * \mathrm{p}<0.05, * \mathrm{p}<0.1$.

\begin{tabular}{|c|c|c|c|}
\hline \multicolumn{4}{|l|}{ PANEL A } \\
\hline \multirow{3}{*}{ BV } & Equation (1a) & Equation (1b) & Equation (2) \\
\hline & $0.5285^{* * * *}$ & $0.5164 * * *$ & $0.5298 * * *$ \\
\hline & $(0.0858)$ & $(0.0839)$ & $(0.0835)$ \\
\hline \multirow[t]{2}{*}{ NI } & $0.7152 * *$ & & $0.7141 * *$ \\
\hline & $(0.2080)$ & & $(0.2096)$ \\
\hline \multirow[t]{2}{*}{ NI_REC } & & $0.6809 * *$ & \\
\hline & & $(0.2023)$ & \\
\hline \multirow[t]{2}{*}{ REC } & & & -0.1228 \\
\hline & & & $(0.5360)$ \\
\hline \multirow[t]{2}{*}{ Constant } & $0.6391 * * *$ & $0.6442 * * *$ & $0.6391 * * *$ \\
\hline & $(0.0824)$ & $(0.0820)$ & $(0.0824)$ \\
\hline Number of Obs. & 1,419 & 1,419 & 1,419 \\
\hline $\mathbf{R}^{2}$ & 0.363 & 0.362 & 0.363 \\
\hline Difference & \multicolumn{2}{|c|}{-0.0343} & \\
\hline \multicolumn{4}{|l|}{ PANEL B } \\
\hline \multirow[b]{2}{*}{ L.NI } & Equation (3a) & Equation (3b) & \\
\hline & $\begin{array}{c}0.4403^{* * *} \\
(0.0494)\end{array}$ & & \\
\hline L.NI_REC & & $\begin{array}{c}0.4190 * * * \\
(0.0493)\end{array}$ & \\
\hline Constant & $\begin{array}{c}0.0368^{* * * *} \\
(0.0020)\end{array}$ & $\begin{array}{c}0.0361 * * * * \\
(0.0021)\end{array}$ & \\
\hline Number of Obs. & 1,187 & 1,187 & \\
\hline $\mathbf{R}^{2}$ & 0.132 & 0.127 & \\
\hline Difference & & 213 & \\
\hline
\end{tabular}




\section{Table 4}

Robustness Analyses II

This Table shows outcomes of value relevance analyses. BV, NI, NI_REC, and REC respectively refer to book value of equity, net income, net income with recycling, and recycling. The dependent variable is market value of equity measured after 3 months from the fiscal yearend. All variables are deflated by lagged market value of equity. The difference row shows the regression coefficient difference between NI and NI_REC. Regression outcomes are obtained by the fixed effects methodology. Year fixed effects are also controlled. Standard errors in parentheses are clustered at both the firm level and the year level. *** $\mathrm{p}<0.01, * * \mathrm{p}<0.05, *$ $\mathrm{p}<0.1$.

\begin{tabular}{lccc}
\hline & Equation (1a) & Equation (1b) & Equation (2) \\
\cline { 2 - 4 } BV & $0.6633^{* * *}$ & $0.5735^{* * *}$ & $0.6406^{* * *}$ \\
& $(0.1363)$ & $(0.1185)$ & $(0.1393)$ \\
NI & $1.6168^{* * *}$ & & $1.6468 * * *$ \\
& $(0.2781)$ & & $(0.2909)$ \\
NI_REC & & $1.4685^{* * *}$ & \\
& & $(0.2467)$ & \\
REC & & & 0.5411 \\
& & & $(0.5555)$ \\
Constant & $0.4795^{* *}$ & $0.5269 * * *$ & $0.4840 * *$ \\
& $(0.1250)$ & $(0.1093)$ & $(0.1242)$ \\
Number of Obs. & 559 & 559 & 559 \\
$\mathbf{R}^{2}$ & 0.583 & 0.581 & 0.585 \\
Difference & \multicolumn{3}{c}{-0.1483} \\
\hline
\end{tabular}

